\title{
The Effect of Playing Blowing Balloon Therapy to Changes in Lung Function in Preschool Children (3-5 Years Old) with Asthma
}

\author{
Sri Sumartini*, Budi Somantri, Tirta Adikusuma Suparto, Septian Andriyani, Sehabudin Salasa \\ Nursing Program, Faculty of Sport and Health Science Education \\ Universitas Pendidikan Indonesia \\ Bandung, Indonesia \\ *srisumartini@upi.edu
}

\begin{abstract}
Asthma disease in Indonesia based on national prevalence in children $\mathbf{4 . 5 \%}$. One therapy for asthma is pursed lips breathing or with playing blowing balloons therapy. This study aims to determine the effect of playing therapy blowing balloon to changes in lung function in preschool children 3-5 years with asthma. The design used in this research is Quasy Experiment, with pretest-posttest approach with control group design. The number of samples taken is 38 respondents' preschool children 3-5 years with asthma in the salak room Hospital TK. II Dustira Cimahi. Sampling with consecutive sampling technique. The result of this research shows p-value 0.000 in intervention group and control group with value ( $p$ value $=0,000, \alpha=0,005)$, so all influence but in the intervention group more influential because respondent in intervention group all respondents change. There is a significant influence of play therapy blowing balloons on changes in lung function in preschool children 3-5 years with asthma.
\end{abstract}

Keywords: pursed lip breathing, blowing balloon therapy, asthma therapy in children

\section{INTRODUCTION}

Asthma affects an estimated 300 million individuals worldwide. It is a serious global health problem affecting all age group, with increasing prevalence in many developing countries, rising treatment costs, and a rising burden for patients and the community. Asthma still imposes an unacceptable burden on healthcare system, and on society through loss of productivity in the workplace and, especially for pediatric asthma, disruption to the family, and it still contributes to many deaths worldwide, including among young people [1-3].

Referring to data from WHO, there are currently around 300 million people who suffer from asthma worldwide. There are around 250,000 deaths caused by asthma attacks each year, with the highest number in low-moderate economies. The prevalence of asthma continues to increase especially in developing countries due to lifestyle changes and increased air pollution [4-6]. Basic Health Research in 2013, reported the prevalence of asthma in Indonesia is $4.5 \%$ of the population, with a cumulative number of asthma cases around 11,179,032. Asthma affects disability and premature death especially in children aged 10-14 years and parents aged 75-79 years. Beyond this age, early mortality is reduced, but it has more disability effects. At present, asthma is included in the 14 major diseases that cause disabilities throughout the world. For this reason we must always be aware of asthma by increasing everyone's awareness to always know the right time to deal with respiratory diseases [7-9].

Basic Health Research (RISKESDAS) in 2017 states that Indonesia in the result of national prevalence for asthma of all ages is $4.5 \%$. The prevalence of asthma in groups over 45 years starts to decline. The prevalence of asthma and cancer in women tends to be higher than in men. Then the prevalence of asthma looks the same between urban and rural areas [10,11]. Asthma tends to be higher in the group with the lowest ownership index. DKI Jakarta (5,2), Banten $(3,8)$, Central Java $(4,3)$, DI Yogyakarta $(6,9)$, East Java $(5,1)$, and in West Java $(5,0)$. Meanwhile, the West Java Health Office in 2013 showed that the asthma rate reached $5.0 \%$, then followed by COPD $5.0 \%$. This proves that asthma is still high in West Java. The prevalence of asthma in women tends to be higher than in men. The results of these data are the results of interviews of all ages and based on symptoms [12].

Asthma that is allowed to be chronic will be fatal. As a result of which will be caused by asthma that can threaten bronchitis, pneumonia and emphysema. Age is often a significant factor, because the first attack in most cases occurs between the ages of 3-8 years. During infancy the attack usually occurs after a respiratory infection. Some children may experience prodromal itching in the neck or upper back just before the attack. So that in asthma patients, especially in children needed intervention or treatment that will reduce or eliminate the asthma [13-15].

Nugroho explains how to manage asthma by carrying out routine asthma treatment and by practicing breathing therapy [16]. According to Brunner and Suddarth, there are several education programs for breathing exercises, namely diaphragmatic breathing and pursed lips breathing [17]. Then according to Wong's, therapy in asthmatic children is many ways, namely with game techniques that can be used for younger children to extend expiration time and increase 
expiratory pressure including blowing cotton balls or PingPong balls on the table, blowing whistles, blowing bubbles or prevent the tissue from falling by blowing it against the wall [18].

Balloon blowing therapy can be analogous to pursed lips breathing in children. According to Smeltzer in the study of Astuti the purpose of pursed lips breathing is to help clients improve oxygen transport, induce slow and deep breathing patterns, help patients to control breathing, prevent collapse and train expiratory muscles to prolong exhalation and increase airway pressure during expiration, and reduce the amount of air trapped [19].

\section{METHOD}

This research is a quantitative study, using quasiexperimental methods which is a study by conducting experimental activities that aim to determine the effects that arise as a result of interventions carried out. This study uses a pretest-posttest approach with a control group (pretest-posttest with control group) [20]. In this study, measurement of pulmonary function or pre-test will be done to preschool children 3-5 years who have asthma, before being given playing therapy to blow balondan and lung function is measured again with peak flow meters after playing balloon blowing therapy. Playing therapy blowing balloons for 3 times a day for 4 days [21].

The sample used in the study amounted to 38 children. The sampling technique in this study is non-probability sampling with which is used is to use primary data sources. The primary data source was obtained from the observation sheet measuring the oxygen saturation value in COPD patients and secondary data obtained from the medical records in the hospital Kindergarten II Dustira Cimahi, and the patient status sheet. The instruments used in this study were pulse oximeters and observation sheets. Analysis of the data that will be presented is the value of pulmonary function or the peak flow of expiration (APE) and standard deviations for univariate analysis while for bivariate analysis using Marginal Homogeneity. This research was conducted from March to April 2017.

\section{RESULT}

The characteristics of asthma patients are preschool children aged 3-5 years. The results of the study can be seen in the following table:

TABLE I. MARGINAL HOMOGENEITY TEST CONTROL GROUP AND INTERVENTION GROUP PURSED LIPS BREATHING THERAPY PLAYING BLOWING BALLOONS

\begin{tabular}{|c|c|c|c|c|c|c|}
\hline \multirow{2}{*}{ Intervention } & \multicolumn{3}{|c|}{ Control Group } & \multicolumn{3}{|c|}{ Intervention Group } \\
\hline & Mean & $S D$ & p value & Mean & $S D$ & p value \\
\hline Peak Expiratory Flow (PEF/APE) & & & & & & \\
\hline $\begin{array}{l}\text { Pursed lips Breathing with blowing balloon } \\
\text { therapy playing Blowing Balloons }\end{array}$ & 37,00 & 2.12 & 0,000 & 61,500 & 3,04 & 0,000 \\
\hline
\end{tabular}

\section{DISCUSSION}

\section{A. Intervention Group Distribution Before Administration of Play Therapy Before Administration of Play Therapy Blowing Balloons}

In asthma patients will have difficulty breathing even some children have difficulty blowing air completely into the balloon, due to respiratory obstruction caused by mucous build up and inflammation. In line with the case above Natalia's study, children are very susceptible to diseases, especially with respiratory diseases. And quite a lot of children are diagnosed with asthma. In children having an asthma attack, the child cannot breathe perfectly. So there are several therapies for children with asthma. One of them is to play blowing a balloon which is analogous to pursed lips breathing [22].

\section{B. Distribution of Intervention Groups After Balloon Blowing Play Therapy}

After being given therapy to play blowing balloons for 3 times a day for 4 days, the majority of respondents experienced a significant change in lung function. According to Astuti's research, pursed lips breathing is a strategy used in pulmonary rehabilitation to reduce shortness of breath. Patients with respiratory disorders will benefit from using these techniques [19]. This strategy was designed to help patients control their breathing patterns, improve breathing muscles, and prevent recurrence of shortness of breath, especially in asthmatic patients. Pursed Lips Breathing can also reduce shortness of breath, so patients can tolerate activities and increase their ability to meet their daily needs. If this technique is carried out every day or routinely and correctly, it can optimize the pulmonary mechanical function.

The results of this study are in line with the Gaurav, at.all study, in an upright sitting position, the increase in diaphragm and external intercostal muscles does not exist because the position of the muscles is perpendicular to the earth's gravity force, while in the semi-Fowler position there is an earth gravity force that works but works in opposition with the main muscular work of inspiration. Likewise with expiratory muscles in an upright position, increased work on these muscles does not exist [23].

\section{Distribution of Control Groups Before Giving Balloon Blown Play Therapy}

Similar to the intervention group, children will want to do balloon blowing therapy with their parents. The procedure given to each group is the same. There is nothing different starting from measuring breathing with a peak flow meter then only standard therapy will be given at the hospital for 3 times a 
day for 4 days. And the majority of respondents in the control group had yellow zone.

This is in line with research by Jayanto's research, which says that before therapy, playing blowing balloons in children has pulmonary function in the yellow category. The yellow colour when measuring lung function in the average respondent before being given a play balloon blowing therapy shows that the average is cautious [24].

\section{Distribution of Control Groups After Balloon Blowing Play Therapy}

Of the 19 control group respondents after researching showed that the majority of respondents who experienced impaired function with mild criteria were $2(5.3 \%)$ children, while for the medium criteria were $17(94.7 \%)$ children. And in the following table explains that there are differences in lung function before and after treatment in the control group of preschool children 3-5 years with asthma in the hospital. Kindergarten. II. Dustira Cimahi. However, in the control group only a few experienced an increase in lung function in the respondent. In contrast to the intervention group respondents who experienced a significant increase through play balloon blowing therapy.

This was explained by the research of Astuti, from the Wilcoxon test results showed no difference in breath patterns before and after treatment in the control group. So that the control group did not experience significant changes in breathing patterns [19].

Then Supriyanto and Nataprawira, explained that nebulizer therapy has advantages, which is the result of nebuliser treatment, which is more dependent on the type of nebulizer used, as well as the drawbacks due to the large enough tool that it can even cause nosocomial infection in children if not clean. And in nebuliser therapy it takes time and expensive drugs for the lower classes. In playing therapy blowing balloons does not require a long time so the child will feel bored with the ongoing therapy [25].

\section{E. Differences in Lung Function Improvement Between Intervention Groups and Control Groups}

Based on the statistical test results obtained by the intervention group with a p-value of $0,000(\mathrm{p}<0.05)$ and a value in the control group p-value of 0.008 ( $p<0.05$ ), it can be concluded that there is an effect of pursed lip breathing or therapeutic exercise playing balloon blowing and standard care, but there is a difference between the intervention group and the control group, where the intervention group with the therapeutic practice of playing balloon blowing shows a significant improvement compared to the group with standard care that is usually done in kindergarten hospitals. II Dustira Cimahi. This study is in line with the research of M. Zul Irfan, et al, revealed that the results obtained to the intervention group and the control group carried out for 2 weeks showed the average value of intervention and significant results that were proven statistically with Wilcoxon $\mathrm{p}$ value $=0.00(\mathrm{p}<0.05)$, it can be concluded that there are differences in values in asthma patients before and after the intervention [26].

\section{CONCLUSION}

This study shows there are differences in the peak expiratory current values before and after the therapeutic intervention playing blowing balloons in the control group. There is a difference in the peak current value of expiration before and after pursed lips breathing therapy playing blowing balloons in the intervention group.

\section{ACKNOWLEDGMENT}

Thank you to the Head of RS. TK II Dustira Cimahi and the Children's as the respondent for the research and data intervention can be carried out. Along with all nurse, hospital staff and students who have helped from the beginning to the end of research activities students who have helped from the beginning to the end of research activities at RS. TK II Dustira Cimahi.

\section{REFERENCES}

[1] Global Initiative For Asthma, Global Strategy For Asthma Management and Prevention, 2017, retrieved from: http://ginaasthma.org/2017-ginareport-global-strategy-for-asthma-management-and-prevention/.

[2] R.P. Navarro, G.K. Rice and K.L. Schaecher, "Asthma management guidelines: updates, advances, and new options," Journal of Managed Care Pharmacy, vol. 13(6 Supp D), pp. 1-16, 2007.

[3] U.G. Lalloo, R.D. Walters, M. Adachi, T. De Guia, A. Emelyanov, C.C. Fritscher and A. Loaiza, "Asthma programmes in diverse regions of the world: challenges, successes and lessons learnt," The International Journal of Tuberculosis and Lung Disease, vol. 15(12), pp. 1574-1587, 2011.

[4] WHO, online serial, 2011, retrieved from: http://who2011.org.

[5] G. D'Amato, L. Cecchi, M. D'amato and G. Liccardi, "Urban air pollution and climate change as environmental risk factors of respiratory allergy: an update," Journal of Investigational Allergology and Clinical Immunology, vol. 20(2), pp. 95-102, 2010.

[6] G. D’Amato, S.T. Holgate, R. Pawankar, D.K. Ledford, L. Cecchi, M. Al-Ahmad and D.J. Baker, "Meteorological conditions, climate change, new emerging factors, and asthma and related allergic disorders. A statement of the World Allergy Organization,"World Allergy Organization Journal, vol. 8(1), pp. 1, 2015.

[7] Basic Health Research (RISKESDAS), online serial, 2013, retrieved from: http://www.riskesda2013.org.

[8] M. Jonsson, A.C. Egmar, E. Hallner and I. Kull, "Experiences of living with asthma-a focus group study with adolescents and parents of children with asthma," Journal of Asthma, vol. 51(2), pp. 185-192, 2014.

[9] S. Oncel, Z.C. Ozer and M. Yilmaz, "Living with asthma: an analysis of patients' perspectives," Journal of Asthma, vol. 49(3), pp. 294-302, 2012.

[10] Riset kesehatan Dasar (Riskesdas), Riset Kesehatan Dasar. Jakarta: Badan Litbangkes Depkes RI, 2017.

[11] S. Timm, M. Frydenberg, C. Janson, B. Campbell, B. Forsberg, T. Gislason and C. Svanes, "The urban-rural gradient in asthma: a population-based study in Northern Europe," International journal of environmental research and public health, vol. 13(1), pp. 93, 2016.

[12] Riset kesehatan Dasar (Riskesdas), Riset Kesehatan Dasar. Jakarta: Badan Litbangkes Depkes RI, 2018.

[13] Suriadi, Yuliani Rita, Nursing Care For Children. Jakarta: CV. Sagung Seto, 2010.

[14] E.D. Bateman, S.S. Hurd, P.J. Barnes, J. Bousquet, J.M. Drazen, M. FitzGerald and E. Pizzichini, "Global strategy for asthma management and prevention: GINA executive summary," European Respiratory Journal, vol. 31(1), pp. 143-178, 2008. 
[22] N. Dewi, Saryono, D. Indrati, "Effectiveness of Pursed Lips Breathing and Inflatable Balloons in Increasing the Peak Flow of Expiration (APE) Bronchiale Asthma Patients in Banyumas Regional Hospital," Nursing Scientific Journal, vol. 3(1), February 2007. pp. 3-13, 2002.

[16] S. Nugroho, “Terapi Pernafasan Pada Asma," MEDIKORA, vol. 5(1), pp. 71-91, 2009.

[17] Bruner and Sudarth, Medical Surgical Nursing Textbook. Jakarta: EGC Medical Book, 2002.

[18] Wong's, Pediatric Nursing Teaching Book. Jakarta: Medical Book, 2009.

[19] L.W. Astuti, Effect of Pursed Lips Breathing on Respiratory Patterns in Patients with Emphysema in Pulmonary Hospital Dr. Ario Wirawan Salatiga, 2014.

[20] Nursalam, Nursing Science Research Methodology. Jakarta: Salemba Medika, 2013.

[21] Tuti, Playing Therapy Blowing Balloons in Preschoolers, 2009, retrieved

from: https://www.yumpu.com/en/document/view/9054835/factor.factor that influences the coverage of initiation /gs.

[23] PT G. Maind, PT R. Nagawarla, PT S. Retharekar, PT S. Gondane, PT N. Bedekar, "Comparison Between the Effects of Pursed Lips Breathing and Mouth taping on Dyspnoea: A Cross Sectional Study," Int J Cur Res Rev, vol. 7(16), August 2015.

[24] K.D. Jayanto, Differences in Lung Function Before and After Pursed Lips Breathing Therapy: Blowing Balloons in Pre-School Children with Asthma in Salatiga District Hospital, 2017, retrieved from: http://k gatheredartikelilmiah.ac.id.

[25] Supriyanto, Bambang, Nataprawira, D. Melinda, "Inhalation Therapy in Children," Sari Pediatrics, vol. 4(2), pp. 67-73, September 2002.

[26] M.Z. Irfan, D.E. Suza, N.F. Sitepu, "Comparison of Breath Buteyko Exercise and Blowing Balloons Exercise Against Changes in the Peak Flow of Expiration in Asthma Patients," Indonesian Nurse Journal, vol.3(2), pp. 93-100, 2019. 